\title{
PENGARUH BRAIN CIRCULATION UNTUK MEMPERKUAT PASAR TENAGA KERJA DALAM MASYARAKAT ASEAN 2015
}

\author{
Arif Darmawan ${ }^{1}$ dan Qisty Anzilni Desiera ${ }^{2}$
}

\begin{abstract}
ASEAN Community 2015 became one of its own products made by ASEAN leaders to ease the creation of a variety of access both in the economic, political, social, cultural, defense and security. Within the ASEAN Community 2015, becoming one of its own steps to open markets more freely so that the movement of the mobility of goods and services can be channeled properly not only in the country in each of the ASEAN countries, however, can be transferred to all other countries. One of the constraints in this regard is how the readiness of the government of a country in ASEAN to face of fierce competition that will take place freely and openly among various countries so that if not handled properly can result in a fairly high unemployment because the foreign labor which is presented in one of the ASEAN countries is a labor that has a high skill. Therefore, the government must also concern related to the brain circulation phenomenon are able to strengthen the various sectors where the government is able to provide its own facilities with the provision of the allocation of funds for research and development and create policies that ensure the products to the convenience of skilled labor to carry out research in homeland then it will strengthen the stability of labor market in ASEAN.
\end{abstract}

Keywords: ASEAN Community 2015, Imbalancing Competition, Brain Circulation, $R \& D$, Stability in ASEAN labor market

\section{Pendahuluan}

ASEAN Community 2015 merupakan salah satu agenda terbesar yang dimiliki oleh masyarakat di Asia Tenggara untuk mewujudkan persatuan dalam satu kawasan regional serta untuk membentuk sebuah komunitas bersama dimana mampu untuk saling memperkuat dan menguntungkan baik dalam aspek politik, ekonomi, sosial, budaya, pertahanan dan keamanan. ASEAN
Community 2015 juga menjadi salah satu acuan atau pedoman tersendiri dimana menjadi sebuah platform besar untuk memicu pertumbuhan perekonomian serta pembangunan dari negara - negara di Asia Tenggara.

Oleh karena itu, secara bertahap para anggota ASEAN berupaya untuk berintegrasi secara penuh melalui sebuah tahapan yang strategis yaitu pada KTT ASEAN ke-14 di

\footnotetext{
${ }^{1}$ Staf Pengajar Prodi Hubungan Internasional, FISIP Universitas Jenderal Soedirman \& Ketua Laboratorium Prodi Hubungan Internasional

${ }^{2}$ Mahasiswa Hubungan Internasional Universitas Jenderal Soedirman.
} 
Thailand, Desember 2008 yang kemudian memastikan berbagai anggota ASEAN bersama - sama meratifikasi Piagam ASEAN (ASEAN Charter) dan sepakat mendirikan ASEAN Community 2015 yang memiliki tiga pilar besar tersendiri yakni $A S E A N$ Political Security Community, ASEAN Economic Community, dan ASEAN Socio - Cultural Communityyang mewakili berbagai aspek untuk tercapainya pembangunan berkelanjutan serta terwujudnya kesejahteraan masyarakat di kawasan Asia Tenggara (Roadmap for an ASEAN Community, 2011:108-115).

Berkaitan dengan hal tersebut, ASEAN Community 2015 menjadi salah satu produk tersendiri untuk tercapainya kemandirian dalam bidang ekonomi yakni untuk mewujudkan kesejahteraan masyarakat di dalam kawasan ASEAN itu sendiri. Terkait dengan hal tersebut, salah satu aspek yang akan dibahas dalam penelitian ini adalah aspek ekonomi dimana dengan adanya $A S E A N$ Economic Community 2015 ini, tentunya, akan terjadi pembukaan pasar secara lebih luas sehingga masyarakat di kawasan ASEAN dapat mengakses berbagai produk dari negara lain dari kawasan ASEAN, terbukanya pasar tenaga kerja yang lebih luas, terdapat pertukaran dalam bidang ilmu pengetahuan dan teknologi, terbukanya lahan untuk akses eksport dan import di ASEAN serta terbukanya persaingan ekonomi di negara negara ASEAN sehingga dapat meningkatkan stabilitas pembangunan di negara - negara ASEAN tersebut.
Dengan mengetahui dan menganalisis berbagai keuntungan dari ASEAN Community 2015 ini, tentunya, dapat memberikan motivasi tersendiri untuk membuat sebuah mekanisme yang mampu menguntungkan berbagai pihak dan meminimalisir berbagai kelemahan yang dihadirkan dengan adanya pembukaan pasar secara bebas yakni dengan adanya pertukaran dalam bidang jasa, barang, tenaga kerja, modal dan teknologi ini. Oleh karena itu, diperlukan pula untuk meninjau berbagai keberhasilan yang telah dilakukan oleh negara - negara yang menjadi 'The Emerging Powers', dimana negara - negara tersebut mampu untuk mengkonsolidasikan berbagai aspek yang mampu menunjang perekonomian mereka (Starr, 2010).

Salah satu mekanisme yang diaplikasikan adalah membuat koneksi dan menjalin hubungan yang kuat dengan diaspora mereka yang tersebar di berbagai negara sehingga para diaspora tersebut mampu untuk memberikan transfer teknologi dan pengetahuan kepada negara homeland-nya. Berdasarkan hal tersebut, muncul berbagai fenomena baru dari berbagai aktivitas migrasi internasional yang kemudian dikenal dengan sebutan 'Brain Drain, Brain Gain, dan Brain Waste'. Fenomena tersebut kemudian dipelajari oleh para peneliti dan kemudian dihasilkan teori baru yang disebut sebagai 'Brain Circulation'yang mampu menjelaskan berbagai elemen tersebut dan hal ini yang menjadi salah satu faktor untuk memperkuat mekanisme yang mampu menunjang 
perekonomian di dalam suatu negara.

Oleh karena itu, salah satu yang perlu menjadi sebuah pertanyaan mendasar tersendiri adalah kesiapan dari berbagai negara di ASEAN terkait dengan hadirnya $A S E A N$ Community 2015 ini serta berbagai hal lainnya yang menyangkut dengan mekanisme dalam perekrutan tenaga kerja dalam suatu negara di ASEAN. Pasalnya, terdapat berbagai kelemahan - kelemahan tersendiri yang perlu dibenahi sebelum ASEAN Community 2015 ini akan terealisasi pada tahun 2015 mendatang.

\section{Pembahasan}

\section{A. Ketidakseimbangan Tenaga Kerja di} Asean

Tenaga kerja menjadi salah satu faktor utama dalam menggerakkan roda pertumbuhan perekonomian dalam sebuah negara. Tenaga kerja menjadi modal yang sangat penting untuk tercapainya kesejahteraan di dalam masyarakat. Oleh karena itu, tenaga kerja memiliki posisi yang sangat vital dalam pembangunan di suatu negara, tidak terkecuali di ASEAN. Dengan adanya hal tersebut, tentunya sangat berkaitan erat dengan kehadiran dari ASEAN Economic Community yang akan dilaksanakan pada tahun 2015 mendatang. Adanya ASEAN Economic Community 2015 ini, tentunya akan membuka berbagai peluang untuk mendapatkan keuntungan yang sebesar - besarnya terhadap arus barang dan jasa di kawasan ASEAN mendatang.
Pembukaan pasar dan terdapatnya liberalisasi pasar menjadi sebuah tantangan yang sangat mendasar dari hadirnya $A S E A N$ Economic Community 2015 ini. Pasalnya, beberapa negara di ASEAN memiliki berbagai kasus yang serupa seperti jumlah tenaga kerja yang produktif bekerja pada berbagai sektor yang informal, kemudian proporsi antara jumlah tenaga kerja produktif dengan minimnya lapangan pekerjaan menjadi permasalahan tersendiri yang mengakibatkan pengangguran hingga adanya tradisi masyarakat ASEAN yang terbiasa memberikan priviledge tersendiri terhadap tenaga kerja asing untuk bekerja di negara mereka sehingga berkurangnya posisi - posisi vital dalam sebuah pasar tenaga kerja. Inilah beberapa faktor yang harus diwaspadai dan harus diberikan upaya - upaya tersendiri sehingga permasalahan tersebut dapat diminimalisir.

Salah satu negara di ASEAN yang dapat menjadi sebuah contoh konkret tersendiri untuk menganalogikan permasalahan tersebut adalah Indonesia. Indonesia merupakan sebuah negara terbesar dianalisis melalui luas wilayah hingga populasi penduduk terbesar di negara ASEAN. Berdasarkan hal tersebut, dapat diketahui bahwa jumlah tenaga kerja Indonesia dapat dikategorikan yang terbesar dan terus bertambah setiap tahunnya. Hal tersebut dapat dianalisis melalui data yang tersedia yaitu pada tahun 2010 jumlah angkatan kerja mencapai 116 juta orang atau naik 2,26 juta orang dibandingkan tahun sebelumnya, sedangkan penduduk yang bekerja juga terjadi 
peningkatan, pada tahun 2010 mencapai 107,41 juta orang naik dari 2009 sebesar 2,92 juta orang (Kementrian Tenaga Kerja \& Transmigrasi, 2011a:26).

Untuk memahami data mengenai jumlah tenaga kerja di Indonesia dapat dianalisis melalui tabel berikut:

Tabel 1: Jumlah Penduduk \& Angkatan Kerja Indonesia 1971-2009 (Sumber: Kementrian Tenaga Kerja \& Transmigrasi)

\section{Jumlah Penduduk dan Angkatan Kerja Indonesia 1971-2009}

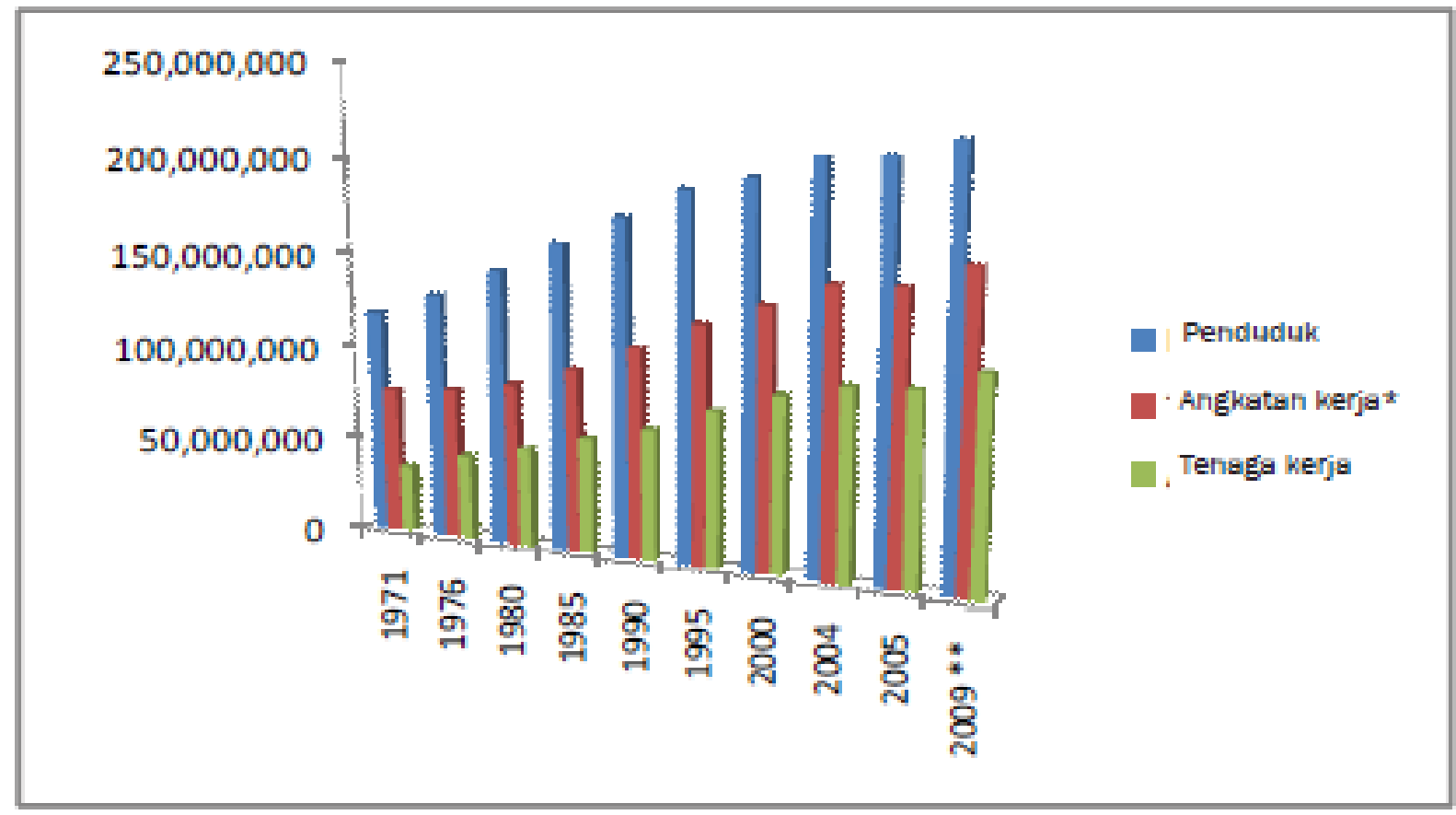

*= Penduduk di atas usia 15 tahun

** Estimasi

Sumber: Survei Angkatan Kerja 2005 
Berdasarkan tabel diatas, yang menjadi permasalahan tersendiri adalah pertambahan angkatan kerja tidak dapat diikuti dengan pertambahan perluasan kesempatan kerja yang mengakibatkan jumlah pengangguran terbuka terus bertambah, sementara itu jumlah setengah pengangguran tetap tinggi. Tingkat pengangguranmeningkat dari 1,7 persen pada 1980 menjadi 6,08 persen dalam tahun 2000 danmenjadi 10,3 persen pada 2005. Tingkat pengangguran terbuka (TPT) di Indonesiapada 2010 mencapai 7,41 persen, ini mengalami penurunan dibanding 2009 yangsebesar 8,14 persen (Kementrian Tenaga Kerja \& Transmigrasi, 2011b:26).

Dengan hadirnya ASEAN Economic Community 2015 merupakan sebuah tahapan tersendiri yang mampu memberikan peluang dan tantangan dalam waktu yang bersamaan. Pasalnya, hadirnya ASEAN Economic Community 2015 ini melingkupi berbagai sektor perekonomian untuk secara bersama sama mampu berintegrasi di antara negara negara anggota ASEAN. Salah satu yang menjadi permasalahan dengan hadirnya ASEAN Economic Community 2015 adalah kesiapan dari setiap negara menghadapi persaingan yang akan berlangsung sangat ketat setiap negara anggota ASEAN dalam mendapatkan pekerjaan yang layak. Inilah yang harus ditinjau kembali.

Pasalnya, apabila menganalisis data mengenai Indonesia, dapat diketahui bahwa berdasarkan jumlah usia produktif yang mampu bersaing dalam ASEAN Economic Community 2015 telah memenuhi persyaratan, akan tetapi, apabila menganalisis lebih mendalam skema dan peraturan yang digunakan dalam ASEAN Economic Community 2015 lebih menekankan kepada liberalisasi tenaga kerja profesional papan atas yang hanya terdapat dalam sektor formal seperti tenaga ahli, dokter, pengacara dan lainnya, serta menuntut untuk memiliki kualitas dan keterampilan yang tinggi untuk mampu bersaing dengan tenaga kerja asing yang akan hadir dengan dilegalkannya $A S E A N$ Economic Community 2015ini, sedangkan, apabila kita menganalisis data yang dimiliki oleh Indonesia yang tentunya juga dapat mendeskripsikan permasalahan yang sama di negara anggota ASEAN lainnya, bahwa sekitar $70 \%$ dari masyarakat Indonesia yakni sebesar73,67 juta orang bekerja dalam sektor informal dan sisanya bekerja pada sektor formal (Kementrian Tenaga Kerja \& Transmigrasi, 2011c:29-30).

Hal tersebut yang menjadi permasalahan tersendiri, karena pemerintah harus mampu membuat sebuah mekanisme tersendiri untuk mengantisipasi dan menanggulangi jumlah pengangguran yang akan bertambah setiap tahunnya apabila tidak mampu bersaing dengan tenaga kerja asing yang akan hadir dari dalam kawasan ASEAN dan beberapa negara lainnya. Tidak hanya itu, permasalahan lainnya adalah jumlah wiraswasta yang masih terbilang rendah di beberapa kawasan di ASEAN sehingga 
produktivitas untuk melakukan aktivitas eksport masih dikategorikan rendah. Inilah yang menjadi wacana tersendiri bagi pemerintah di beberapa negara di kawasan ASEAN untuk meninjau kembali terkait kesiapan dalam beberapa sektor tersebut sehingga mampu membuat mekanisme yang baik terkait dengan sistem perekrutan tenaga kerja hingga membentuk sebuah strategi yang mampu digunakan secara berkesinambungan.

\section{B. Brain Circulation}

Migrasi internasional menjadi fenomena tersendiri dalam perkembangan sejarah dunia. Pasalnya, terjadinya migrasi internasional ini erat kaitannya dengan adanya sejarah kelam yang dimiliki dunia secara global, yaitu adanya peperangan yang terjadi antara satu negara dengan negara lainnya sehingga menimbulkan keinginan tersendiri bagi penduduk suatu negara untuk melakukan migrasi ke negara lainnya yang memiliki prospek lebih baik untuk membangun kehidupan.

Migrasi internasional juga dikenal sebagai salah satu faktor pendorong terjadinya penyebaran diaspora yang telah menjadi sebuah aktivitas global di dunia hingga saat ini (N.V Hear, 1998:17-21). Perkembangan dunia yang cepat dengan hadirnya globalisasi membuat pola tersendiri dari adanya penyebaran diaspora melalui migrasi internasional yaitu adanya dampak dari ketidaksejahteraan yang tercermin dari pendapatan yang tidak sesuai serta adanya level kemiskinan yang dikategorikan cukup tinggi dari negara homeland-nya yang menjadi salah satu alasan kuat dari penyebaran diaspora dari suatu negara ke negara lainnya (Ozden \& Schiff, 2006:20).

Adanya fenomena tersebut, yang kemudian menjadi salah satu trend yang menjalar ke seluruh dunia, baik dari negara negara di benua Afrika, Eropa, Amerika, Asia hingga Australia yakni pasca berakhirnya peperangan yang merupakan historis tersendiri dalam ranah internasional.

Berdasarkan paparan tersebut, yakni adanya migrasi internasional yang kemudian mengakibatkan adanya penyebaran diaspora telah mengembangkan salah satu fenomena baru tersendiri dalam kehidupan internasional. Fenomena tersebut adalah Brain Drain, Brain Gain dan, Brain Waste, yang menggambarkan bagaimana penyebaran diaspora yang didorong oleh faktor migrasi internasional berpengaruh terhadap hilangnya penduduk yang memiliki berbagai keahlian dari homeland ke hostlandnya atau adanya transfer sumber daya manusia tersebut dapat berguna bagi negara lain yang menjadi destinasinya, hingga tidak terpakainya keahlian yang dimiliki oleh diaspora yang tersebar disuatu negara. Seiring dengan perkembangan zaman, istilah Brain Drainversus Brain Gain telah berganti dalam suatu logika analisis baru yang disebut dengan Brain Circulation yang merupakan hasil pengembangan dan perubahan dari fenomena Brain Gain dan Brain Drain.

Brain Circulation adalah sebuah fenomena yang secara fundamental 
menggantikan fenomena Brain Drain versus Brain Gain dalam ranah global yaitu dunia yang berbasis pengetahuan. Orang berkualifikasi tinggi yang melakukan perpindahan di antara negara-negara dan lembaga-lembaga yang berbeda, sehingga memperoleh, berbagi, dan menyebarkan pengetahuan mereka. Brain Circulation adalah salah satu faktor paling penting yang mempengaruhi pertumbuhan ekonomi negara dan dengan adanya hal tersebut, turut memberikan kontribusi kepada pertumbuhan daya saing.

Adanya penekanan terhadap kombinasi dari strukturindustri, kepercayaan, pembelajaran dan kewirausahaan serta adanya infrastruktur keuangan untuk start-up, hingga peran negara dalam memfasilitasi transfer teknologi bisa diartikan sebagai kunci sukses sementara dalam merangsang Brain Circulation. Pemahaman konseptual fenomena sirkulasi otak ditafsirkan sebagai hasil dari evolusi Brain Drain dan fenomena Brain Gain (Marcinkeviciene, 2009: 55).

Fenomena Brain Circulation merupakan fenomena tersendiri dimana imigrasi yang memiliki keterampilan tinggi semakin menguntungkan kedua belah pihak dan adanya global circulation terhadap para pekerja yang memiliki high-skilled dari negara miskin ke negara kayaatau sebaliknya, dan kembali membuka kemungkinan baru untuk pembangunan ekonomi (Saxenian, 2002: 28-31). Inilah salah satu pemahaman baru terkait dengan hubungan diaspora dengan adanya fenomena Brain Circulation tersebut. Untuk memahami, fenomena Brain Circulation tersebut dapat dianalisis melalui diagram berikut (Yun-Chung, 2007) : 


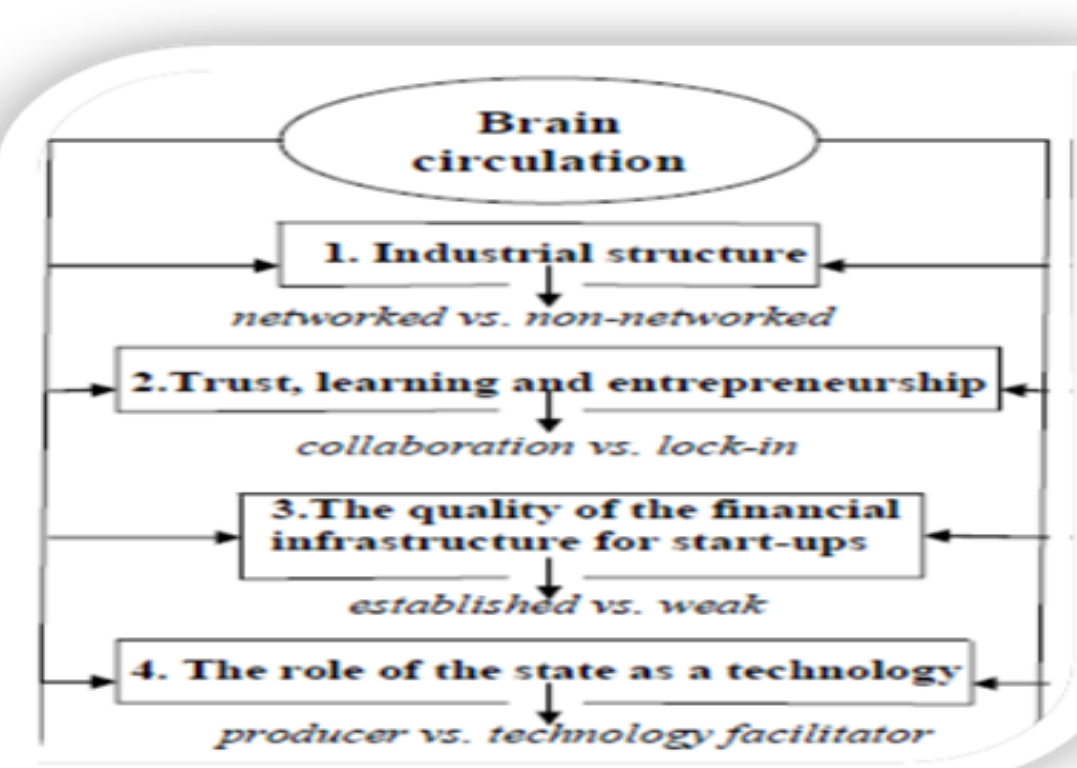

Dari diagram diatas, dapat dipahami bahwa pertama harus ada sistem industri desentralisasi dengan pembagian kerja yang kuat dan inovasi antara perusahaan jaringan. Kedua, ekonomi diaglomerasi antara dua tempat, organisasi harus mendorong kewirausahaan dan pembelajaran antara perusahaan pada tingkat regional. Ketiga, modal sangat penting untuk start-upsteknologi. Keempat, peran negara dalam memfasilitasi transfer teknologi harus signifikan. Pemerintah harus mendanai sektor swasta, karena mereka lebih menekankan pada kegiatan mereka dalam inovasi, sehingga merangsang pembangunan ekonomi negara dan daya saingnya. Merangkum analisis tersebut, perlu untuk menyoroti bahwa kombinasi dari empat elemen struktur ini bisa menjadi kunci keberhasilan sementara dalam menstimulasi fenomena Brain Circulation.

\section{Keberhasilan Menerapkan Brain} Circulation dalam Meningkatkan dan Menguatkan Sektor Ekonomi: Pelajaran dari Korea Selatan dan China

Brain Circulation menjadi fenomena tersendiri yang dapat menunjang perekonomian dalam sebuah negara apabila mampu digunakan secara lebih efektif dan efisien oleh berbagai negara di dunia. Hal tersebut sudah terbukti dengan berbagai keberhasilan yang didapat oleh beberapa negara yang saat ini dikenal sebagai negara 'The Emerging Powers' karena negara negara tersebut mampu untuk menstimulasikan berbagai aspek sehingga mampu mencapai tahapan tertinggi dalam perekonomian internasional. Fenomena keberhasilan 
menstimulasikan Brain Circulationini, dapat dianalisis melalui strategi yang digunakan oleh Korea Selatan dan China untuk mengakselerasikan berbagai aspek ekonomi hingga pada akhirnya mampu untuk mencapai tahapan tertinggi dalam ranah internasional.

Pemerintah Korea telah meyadari bahwa mereka telah memiliki kelompok diaspora terbesar di Amerika, yakni dengan para mahasiswa yang menempuh pendidikan di Amerika. Terdapatnya peningkatan tingkat pengembalian ilmuwan dan insinyur yang sangat terampil dan berpendidikan merupakan hasil dari boomimg economy dan kondisi kehidupan yang lebih baik. Terdapat beberapa faktor yang menjadi kekuatan pendorong utama untuk Brain Circulation di Korea adalah sebagai berikut (Kocaoglu, 2008: 314-327):

1. Pembangunan ekonomi Korea telah berkembang selama tiga dekade terakhir dan terus meningkatkan

2. Pengeluaran Korea terkait dengan Research and Development telah meningkat dari jumlah PDB yang dimilikinya yaitu dari $0,25 \%$ PDB pada tahun 1963 dan bisa mencapai 2,61\% PDB pada tahun 1994

3. Mengubah struktur industri negara: Industrialisasi Korea

4. Pemerintah Korea telah mengadopsi kebijakan untuk memanfaatkan keahlian yang dibutuhkan dari luar negeri Korea misalnya Program "Brain Pool", Korea Scientist\&Engineer's organization abroad
5. Dukungan dari Perusahaan Korea Selatan besar misalnya Samsung, Hyundai dan Daewoo. Mereka telah mengumpulkan sumber daya yang diperlukan dan modal untuk berinvestasi dalam $R \& D$ dan infrastruktur dasar.

Inilah beberapa langkah yang dilakukan oleh pemerintah Korea yang sangat teliti melihat peluang dibalik fenomena Brain Circulation, tidak hanya itu, baru-baru ini, pemerintah Korea tidak hanya berusaha untuk menarik para profesional Korea yang sangat terampil di luar negeri, tetapi juga mendorong Brain Circulation dengan demikian mencoba untuk mendorong tenaga kerja ilmuwan asing di posisi penelitian permanen dengan memperkenalkan sistem "kartu hijau". Tindakan utama yang dilakukan oleh pemerintah Korea Selatan adalah menstimulasi proses Brain Circulation untuk memastikan komunikasi dari pemerintah, sektor swasta dan sektor akademik. Inilah contoh keberhasilan tersendiri dari pemerintah Korea Selatan terkait mengkonsolidasikan berbagai aspek untuk meningkatkan kekuatan perekonomian dalam ranah global.

Salah satu negara lainnya yang telah mampu untuk menerapkan sistem Brain Circulation adalah China. Hal tersebut dimulai ketika kesadaran pemerintah China terkait dengan adanya fenomena Brain Drain di China yang terjadi secara masif pada tahun 1992 yang mengakibatkan pemerintah China mengalami kerugian dalam bidang perekonomian dengan hilangnya masyarakat 
yang memiliki high-skilled dan profesional ke negara - negara lainnya yang memberikan keuntungan tersendiri bagi para diaspora China tersebut (Han, 2008a: 15-16). Dengan menyadari adanya hal tersebut, pemerintah China berupaya untuk menjaga dan memelihara hubungan dengan para diasporanya melalui kebijakan yang fleksibel terhadap diasporanya di seluruh dunia.

Adapun, berbagai kebijakan tersebut mencakup berbagai hal yang berkaitan dengan Brain Circulation itu sendiri adalah sebagai berikut (Han, 2008b: 15-16):

1. Pemerintah China berupaya untuk mencoba menarik perhatian dari para pekerja terampil dengan penciptaan pusat post-doctoral, pembentukan dana penelitian dan pendanaan kembali bagi para profesional diaspora China, pembentukan universitas kelas dunia, pembentukan pusat pengenalan kerja yang mencakup kebijakan preferensial untuk memberikan keadaan kehidupan yang lebih baik dan kondisi pekerjaan yang lebih baik bagi para diaspora China yang kembali ke China.

2. Adanya aplikasi sistem legislasi yang bermanfaat bagi peneliti, pelaksanaan program " Melayani Bangsa " tanpa " Kembali ke Negara " merupakan kebijakan untuk mendorong diaspora Cina yang tinggal di luar negeri untuk terlibat dalam tujuh jenis kegiatan yang dapat membantu China.

3. Pembentukan peraturan yang mempermudah masuk dan keluar untuk para diaspora China yang sangat berbakat dan investor yang memegang kewarganegaraan di luar negeri dan penciptaan taman teknologi untuk kembali ke luar negeri.

Inilah beberapa kebijakan dari pemerintah China untuk memelihara hubungannya dengan diasporanya diseluruh dunia dengan mempertimbangkan faktor Brain Circulation sebagai salah satu acuannya.

Para diaspora China ini memiliki berbagai konektivitas dan kedekatan dalam bidang jaringan bisnis maupun dalam hal kekerabatan yang mampu membantu para diaspora China tersebut untuk mampu bertahan diluar dari wilayah China. Brain Circulation sendiri sangat erat kaitannya dengan adanya pertumbuhan daya saing dan juga perekonomian. Salah satu mekanisme yang digunakan oleh diaspora China dalam mewujudkan kesejahteraan serta turut berkontribusi dalam pembangunan nasional China adalah sebagai berikut (Chaerowonsak, http:// www.kriengsak.com):

1. Memfasilitasi perdagangan internasional dan investasi

Sebuah jaringan hubungan kekerabatan dan bahasa yang digunakan oleh diaspora Cina memberikan kontribusi untuk membuat bisnis lebih mudah melintasi perbatasan. Hubungan jaringan tersebut telah cepat membangun keandalan dan aliran data 
perdagangan dalam jaringan. Selain itu, pengetahuan tentang budaya lokal memberikan kontribusi untuk perdagangan kerjasama antar negaranegara berkembang yang memiliki peraturan komersial lemah.Dalam hal investasi langsung internasional, China telah menjadi target investasi dari seluruh dunia sejak membuka bangsa ke dalam sistem kapitalis. Nilai FDI selama 2001 - 2011 di Cina telah meningkat rata-rata sebesar $10,6 \%$ per tahun dan investasi global sebesar 8\% karena adanya peranan dari diaspora China itu sendiri.

2. Menciptakan bisnis yang efisien untuk kompetisi

Di masa lalu, sebagian besar migran China di seluruh dunia adalah buruh. Buruh Cina Rantau, terutama yang berasal dari zaman kolonial, memberikan kontribusi terhadap pembangunan ekonomi dan industri bagi negara-negara tuan rumah yang kurang dalam angkatan kerja (Lai, 2009: 2854).Namun, salah satu karakteristik jelas dari etnis Cina adalah menjadi pengusaha. Sejumlah besar migran Cina miskin dan tidak berpendidikan mampu membentuk secara kuat untuk menciptakan bisnis berukuran besar. Informasi bagi para pemimpin bisnis dunia menegaskan bahwa sepuluh orang terkaya di Thailand, Indonesia, Malaysia, dan Singapura termasuk 8 etnis Cina (Forbes, 2012).

3. Kebijakan Pemerintah China yang mampu untuk memperkuat hubungan baik secara kultural hingga hubungan bisnis sehingga tercipta rasa keterikatan antara negara China dengan para diasporanya untuk bersama - sama meningkatkan perekonomian untuk memperkuat pembangunan.

Beberapa hal tersebut, menjadi sebuah paparan tersendiri dimana pemerintahan mampu secara lebih teliti melihat berbagai peluang yang ada kemudian menjadikan hal tersebut sebagai stimulus tersendiri untuk meningkatkan pendapatan yang tentunya akan sangat bermanfaat bagi kesejahteraan masyarakat dan pembangunan berkelanjutan di kedua negara tersebut yakni Korea Selatan dan China.

\section{Kesimpulan}

Memahami terkait dengan adanya fenomena Brain Circulation ini dengan kehadiran ASEAN Economic Community 2015 menjadi momentum tersendiri bagi pemerintah di beberapa negara ASEAN untuk mengaplikasikan hal yang serupa dengan berbagai persiapan - persiapan terlebih dahulu. Permasalahan tenaga kerja di berbagai negara di ASEAN telah dianalogikan melalui permasalahan tenaga kerja di Indonesia yang mampu menjadi contoh tersendiri dimana negara anggota ASEAN lainnya masih memiliki permasalahan serupa yakni proporsi tenaga kerja yang bekerja di sektor informal 
lebih banyak dibandingkan di sektor formal, kemudian, terjadinya ketimpangan antara perekrutan tenaga kerja asing dengan tenaga kerja domestik karena terdapat tradisi privilege bagi tenaga kerja asing, belum adanya mind mapping sektor potensial setiap daerah yang mampu memonitor potensi daerah untuk dikembangkan sebagai salah satu sarana berwiraswasta dan mendirikan UKM dan berbagai hal lainnya.

Oleh karena itu, dibutuhkan sebuah mekanisme baru yang mampu untuk memikat berbagai komponen di ASEAN untuk mampu bersama - sama menanggulangi berbagai kelemahan yang akan dihadapi melalui ASEAN Economic Community 2015 tersebut yaitu dengan menggunakan Brain Circulation sebagai salah satu langkah mandiri untuk menciptakan lingkungan ekonomi yang berbasis kepada koneksi antar diaspora untuk melakukan transfer teknologi dan pengetahuan sehingga pemerintah mampu mengantisipasi terjadinya pengangguran hingga ketimpangan tenaga kerja asing yang akan menguasai berbagai sektor vital di ASEAN.

Namun, untuk menerapkan hal tersebut pemerintah di berbagai negara ASEAN harus sudah mulai mempersiapkan sebuah kebijakan baru yang mampu untuk menarik perhatian diaspora sehingga memiliki rasa keterikatan untuk sharing benefit. Salah satu tahapannya adalah mempersiapkan alokasi dana tersendiri bagi para diaspora tersebut untuk melakukan riset sehingga mampu untuk mengembangkan research and development yang menjadi salah satu penunjang dari kemandirian sebuah negara untuk menciptakan inovasi dan mendapatkan keuntungan yang sebesarbesarnya, kemudian, pemerintah harus memiliki sistem perekrutan tenaga kerja yang lebih ketat sehingga akan mengantisipasi ketidakseimbangan tenaga kerja di ASEAN, standar pengajaran dan pendidikan harus ditingkatkan agar mampu bersaing dengan tenaga kerja asing serta harus ada suatu kegiatan untuk mempromosikan pengetahuan tentang mengembangkan usaha di ASEAN dan bisnis untuk berbagai diaspora ASEAN yang tersebar diseluruh dunia. Inilah tahapan tahapan tersendiri yang dengan sendirinya akan mampu menstabilkan berbagai hal dari adanya liberalisasi tenaga kerja di ASEAN. 


\section{Daftar Pustaka}

Association of Southeast Asian Nations. Roadmap for an ASEAN Community 2009 - 2015. Jakarta: ASEAN Secretariat. 2009.

Chaerowonsak, Kriengsak. The Global Chinese Diaspora - Creating Wealth, Contributing to National Development Abstract. Harvard University. Available at: http:// www.kriengsak.com.

Daugeline, Rasa and Marcinkeviciene, Rita. Brain Circulation: Theoretical Considerations. Kaunas University of Technology. 2009.

Forbes. 2012a. Indonesia's 40 Richest. [Online]. Available: http://www.forbes.com/lists/2011/80/ indonesia-billionaires-11_land.html.

Hear, N.V. New Diasporas: The mass exodus, dispersal and regrouping of migrant communities. London: UCL Press Limited. 1998.

Kementerian Tenaga Kerja dan Transmigrasi. Perkembangan Ketenagakerjaan di Indonesia. Jakarta: Kantor ILO Indonesia. 2011.

Lai, W. L. Asian Diasporas and Tropical Migration in the Age of Empire: A Comparative Overview. Journal of Chinese Overseas, 5(1). 2009.

Özden, C dan Schiff, M. International Migration, Remittances, and The Brain Drain. A copublication of The World Bank and Palgrave Macmillan. 2006.

Saxenian, A. 2002. Brain Circulation: How High-Skill Immigration Makes Everyone Better Off. The brookings review (1), 28 - 31. Available at: http://people.ischool.berkeley.edu/ anno/ Papers/brain-circulation brookings-review-2002.pdf. 2002. 
Suntharasaj, P., \& Kocaoglu D. F. Enhancing A Country's Competitiveness through "National Talent Management Framework". Management of Engineering \& Technology. 2008.

Starr, Pamela. Globalization, Interdependency and Public Diplomacy. Retrieved on August $30^{\text {th }}$ 2014. Available at: http://uscpublicdiplomacy.org/pdin_monitor_article/globalizationinterdependency-and-public-diplomacy. 2010.

Yun-Chung, C. The Limits Of Brain Circulation: Chinese Returnees And Technological Development In Beijing. Available at: http://www.cctr.ust.hk/articles/ pdf/ WorkingPaper15.pdf. 2007.

Zweig, D., Fung C. S., \& Han D. Redefining the Brain Drain: China's "Diaspora Option". Science, Technology \& Society. p.15-16. 2008. 